\title{
sciendo
}

DOI 10.2478/sbe-2019-0004

SBE no. 14(1) 2019

\section{CONSIDERATIONS REGARDING THE RELEVANCE OF DIRECT FOREIGN INVESTMENTS IN THE GLOBAL ECONOMY}

\author{
FRATICIU Lucia \\ Lucian Blaga University of Sibiu, Romania
}

\begin{abstract}
:
It is well known that the current business world, and also the investments, today are based on the global markets expansion. Contemporary reality shows us the image of a world which is irreversibly evolving towards the businesses globalization and the companies' internationalization. The internal markets often become overcrowded, and the companies access more profoundly the global marketplace, which not only provides a place for all competitors, but also represents a source of new advantages for all. In the context of globalization the investment activity has gained new dimensions, becoming a global one, with serious implications, which manifest itself over the national economies and also over the world economy. Starting from these premises, the present paper's purpose is to analyze a current, important and intensely debated issue, namely, the direct foreign investments, pointing out the main elements of their historic development and highlighting their fundamental role for the economic development of a country. Thus, here are reviewed some of the indisputable benefits of direct foreign investments generated within the country - as a dynamic development engine. Beyond the beneficial effects, which unequivocally denote the importance of drawing direct foreign investments, we try to answer the question "Can be identified negative effects of direct foreign investments which affect the receiving country?"
\end{abstract}

Key words: transnational companies, globalization, foreign direct investment, host country

\section{Introduction}

Fully grounded, globalization it is considered to be one of the broadest phenomena that marks the contemporary economic and social life in the world. It doesn't matter if we are among the globalization advocates or its opponents, the globalization impact and its effects are obvious. From this point of view the most important aspects are related to the investment's amount and the location of the direct investment, business' relocation, increasing the volume of operations performed, faster transmission of crises due to openness and interdependence or economic competition between the states and regions. 
The production, services, commerce, finances, the transport and the capital, under the impact of this phenomenon, become parts of a whole for which the physical boundaries of states or continents have no relevance (Negrea, 2012).

In the global economy, an interconnected economy, the main actors are represented by transnational corporations which generally come from economically and socially highly developed countries, and which are no longer satisfied with the local market, which became insignificant, choosing to transcend the borders at one point. One of the essential qualities of the transnational enterprises is that of being the generators of direct foreign investments, generating or not, positive effects over the economy of the host countries by their investments.

In the contemporary general context, it can be noticed that the remarkable expansion of foreign direct investment in recent decades, transformed globalization into an ordinary daily aspect for each individual, affecting the ways of communication or leisure, the working place or purchased products. This state of affairs it is not surprising at all, given the fact that practically there is no economic sector in which multinational companies not to be present, being responsible for about two-thirds of the global trade, while the trade between the multinational companies various subsidiaries represent about one-third of the world trade (Biró, 2013). It is fully justified that multinational companies are "determinant factors and results (in the same time) of the globalization process" (Ogrean, Herciu, 2012, p.138).

\section{What is the foreign direct investment?}

As it is stated by the Organization for Economic Co-operation and Development, the direct foreign investment is "a category of investment that reflects the objective of establishing a lasting interest by a resident enterprise in one economy (direct investor) in an enterprise (direct investment enterprise) that is resident in an economy other than that of the direct investor. The lasting interest implies the existence of a long-term relationship between the direct investor and the direct investment enterprise and a significant degree of influence on the management of the enterprise". The capital placement and its materialization in industrial companies, transport, agricultural, construction, etc., gives to the foreign investors the possibility of taking the decisions and the right to control the project at the level of management, technology, marketing, etc.

In the opinion of some specialists (Ilie, 2009, p.9) the foreign direct investments represent "complex international flows involving financial, technological, management and organizational expertise during a wider period of time, as well as the company's entrepreneurial control or the private individual's taken as an investor in order to carrying out productive activities in a different economy other than the one in which the company or the person is a resident."

Attracting foreign capital in the form of foreign direct investment it is considered to be (Scholz, 2007) a specific activity, well defined at internationally level and which had been initiated and also improved in the developed countries. Usually, these countries have the quality of being, in general, the main global investors, but also the main recipients of direct investment flows. We can notice that at the level of the world economy the foreign 
direct investment usually get focused, on a significant extent, toward the developed countries, although the interest for this type of investment it is a special one, especially in the case of developing countries because they are the ones who have a severe and real need for foreign capital inflows, but at the same time, of a modern managerial experience and know-how. Of course, any investment involves a certain degree of risk, which is a defining element of the concept of investment, but in the developed countries the investment risk it is not as high as the one from the developing countries. This is the explanation offered by the implementation of the foreign investment projects of FDP form (foreign direct investment) in a significant percentage in the developed countries.

Taking into account the purpose of direct investments are included some specific types of operations (Horobeţ \& Popovici, 2017 ) as follows:

- $\quad$ Buying / selling existing capital in the form of acquisitions and mergers;

- Greenfield investments- completely new type of investments, usually initiated by companies with a superior technology and modern management. Reflecting a high level of confidence in the host country's economy, they refer to the forms of FDP in which the mother-company builds its operations in a host country from scratch on a land without existing infrastructure. In general, Greenfield investments take place where it is identified a major development potential in certain economic sectors, due to the risks they face, and given the high costs generated by building the facilities and setting them into operation. So, in the case of these operations, the implementation effort it is extensive, as well as the implementation period.

- Expansion of capital (additional new investments);

- Financial restructuring.

Some specialists (Stoina, 2008), taking into account the reasons behind the expansion of organizations, identify the following categories of foreign direct investments:

- Foreign direct investments which are looking for specific - resource for the companies which decide to invest in other countries either to access resources that are not available in their country of origin or to obtain certain resources at a real lower cost than the one in the country of origin;

- Investments in search of new markets - it is the case of companies which invest in a certain region with the purpose of answering to a demand for goods and services;

- Investments in search of efficiency- based on the motivation of the production processes' rationalization or attaining some benefits out of the activities which are geographically dispersed. This category of foreign direct investment places at the first level the skills and abilities developed, the nature of demand, the quality of the local support industries and also the governmental policy at macro and microeconomic level;

- Foreign direct investments seeking for strategic assets - the main objective of multinational companies is to support and promote their global competitiveness. In this context (Radu, 2007), the multinational corporations' competitivity, both at the level of the host country and also analyzing the economy of the country of origin, can be studied by analyzing the multinational corporations' strategies, alliances and management and, last but not least, through the foreign direct investment they have 
completed.

- Other types of foreign direct investments - a category which it includes three subcategories, namely: escape investments, support investments and passive investments. The first ones are based on the companies' intention of avoiding restrictive legislation or macroeconomic policies applied in the countries of origin. The support investments are characterized by the fact that they are designed to support the company's activities, while the passive investments represent rather the portfolio investments' attributes.

In terms of evolution in time, the motivation to internationalize the companies, we find it very important to emphasize the fact that if, by the early 1990's the transnational companies were in search of accessible markets and resources, especially workforce and raw materials in the developing countries, the low costs, especially regarding the workforce, has ceased to be the main argument for the investment, in the context of technical progress and the increasing products' complexity was demanded a well-qualified workforce (Bîrsan, Masca, 2012 ). Therefore, to some extent, a lower amount of foreign investment in Romania, compared to other former communist countries, was also due to the shortage of highly qualified workforce. Indeed, another aspect which the companies, the businesses people which are interested in expanding their businesses is represented not only by the quantity but also by the quality of the human resources, along with other aspects, such as economic, political and legislative stability (Tudose, 2012), transportation and information infrastructure etc. There is no doubt that the existence of a negative perception among investors regarding the political and economic context often hinder the decision to invest, even if those markets offer important opportunities. (Ciobanu, 2015).

\section{The historic overview of the foreign direct investment}

Cohn (2016) classifies the historical development of foreign direct investments into 3 periods/stages: pre -World War II, the mid 1940s to mid 1980s and 1990s to the present. During the pre-World War II period, Britain dominated the flux of FDls . Cohn discusses the reasons why, in the absence of investment safeguards, investments were still secure: the rapid progress in communications, technology and transportation, lower economic and political risks because of convertibility of currencies and the colonial status of countries, etc. Evidently, there was a change in the investment flux after World War I due to political instability, the events of the 1929 Crisis, that modified after World War II. Cohn states : “...a number of countries imposed restrictions on inward FDI the Soviet Union nationalized foreign property, and the gold exchange standard was suspended...It was not until after World War II that the vigorous growth of MNCs and FDI would resume".

During mid-1940s to mid-1980s there have been some changes to the inward and outward 'FDIs world map'. The United States replaced Britain as the dominant source of FDls after World War II. US companies represented $47.1 \%$ of outward FDI stock in 1960 compared to the British share of $18.3 \%$. In general, the FDI processes and flux have been expended mainly because of high economic growth period experienced by the United States and Europe. Since late 1960s, the United States' share of outward FDI stock decreased from $47.1 \%$ in 1960 to $32.3 \%$ in 1985 , whilst shares of Japan and Germany 
mainly increased doe to their recovery after the war. Japan's share was still small $(6 \%$ in 1985 ) because of economic and cultural barriers kept in place by the government. DCs accounted for a 99\% share of outward FDI stock in 1960 and $90 \%$ in 1985 . The interesting aspect about this stage of FDI is that developed countries were the main source and the main recipient of inward FDls. Less developed countries kept many barriers in place although the five largest less developed countries recipients of inward FDI stock in 1985 were Hong Kong, Brazil, Indonesia, Saudi Arabia and Mexico (Cohn, 2016).

The 1990s to the present phase, despite various financial crises, have increased the flow of FDls.

The next table illustrates a growth of inward and outward FDI as a share of GDP for developed countries from 8.9 and $11.2 \%$ in 1990 to $36.4 \%$ and $47.1 \%$ in 2013 .

Table 1. Share of Inward and Outward FDI Stock as a Percent of GDP(Source:Cohn, 2016, p.301)

\begin{tabular}{|c|c|c|c|c|c|c|}
\hline & 1990 & 1995 & 2000 & 2005 & 2010 & 2013 \\
\hline \multicolumn{7}{|l|}{ DCs } \\
\hline Inward & 8.9 & 11.0 & 22.4 & 25.1 & 31.7 & 36.4 \\
\hline Outward & 11.2 & 14.7 & 28.0 & 31.9 & 42.3 & 47.1 \\
\hline \multicolumn{7}{|l|}{ United States } \\
\hline Inward & 9.4 & 13.7 & 26.9 & 21.4 & 22.7 & 29.4 \\
\hline Outward & 12.7 & 18.5 & 26.0 & 27.6 & 31.9 & 37.8 \\
\hline \multicolumn{7}{|l|}{ Japan } \\
\hline Inward & 0.3 & 0.6 & 1.1 & 2.2 & 3.9 & 3.5 \\
\hline Outward & 6.5 & 4.5 & 5.9 & 8.5 & 15.1 & 20.3 \\
\hline \multicolumn{7}{|l|}{ Germany } \\
\hline Inward & 6.5 & 6.6 & 14.4 & 17.2 & 21.7 & 23.4 \\
\hline Outward & 8.8 & 10.6 & 28.7 & 33.5 & 44.3 & 47.0 \\
\hline \multicolumn{7}{|l|}{ U.K. } \\
\hline Inward & 20.1 & 17.3 & 31.0 & 36.7 & 49.5 & 63.3 \\
\hline Outward & 22.6 & 26.3 & 61.8 & 52.4 & 71.3 & 74.3 \\
\hline \multicolumn{7}{|l|}{ France } \\
\hline Inward & 7.9 & 15.1 & 29.4 & 41.5 & 38.5 & 39.5 \\
\hline Outward & 9.0 & 24.2 & 69.7 & 57.6 & 59.0 & 59.8 \\
\hline \multicolumn{7}{|l|}{ Italy } \\
\hline Inward & 5.3 & 5.8 & 11.1 & 13.3 & 16.0 & 19.5 \\
\hline Outward & 5.3 & 9.4 & 15.4 & 13.7 & 23.8 & 28.9 \\
\hline \multicolumn{7}{|l|}{ Canada } \\
\hline Inward & 19.4 & 20.9 & 28.8 & 29.3 & 36.7 & 35.3 \\
\hline Outward & 14.6 & 20.0 & 32.1 & 33.4 & 39.4 & 40.1 \\
\hline
\end{tabular}

Cohn(2016)discusses the factors that can explain the rise of FDls flows, both inward and outward: mainly the spread of deregulation and neoliberalism, the break up of Soviet Union and the growth of multilateral trade negotiations. These factors allowed multinational companies to expand their activities across the globe. The following changes can be established: the United States lost their leading position as a source of FDIs; the share of outward FDI stock of developed countries declined and the share of outward FDI stock of less developed countries and transition countries increased. The trends regarding the inward FDI stock since 1990 shows a growth of incentives for multinational companies offered by less developed countries and transition economies and their share of inward FDls increased from $23.2 \%$ to $31.9 \%$ during $1990-2014$. 
In terms of geographical regions, Africa holds only $2.7 \%$ of inward FDI stock in 2014, whilst Asia has 21.9\% of inward FDI stock and 7.3\% for Latin America. As Cohn (2016) states: "East and South-East Asia constitute the largest recipient region for FDI inflows in the world".

According to the UNCTAD World Investment Report (2018): "Global foreign direct investment (FDI) flows fell by $23 \%$ to $\$ 1.43$ trillion" (pag. xi). The figures represent data for 2017. The report acknowledges the fall in cross-border merger and acquisitions as a cause for this phenomenon. Given this framework, it is remarkable that FDI flows to developing countries such as in Asia remained stable whilst they have increased in Latin America and Carraibe.The exception remains Africa with a downturn of $21 \%$ from 2016 in FDI flows.

Estimates of global FDIs for 2018 illustrate 'fragile growth' (pag. xi). The main factor that accounts for this downturn is the rate of return on investment that has evolved from 8.1 in 2012 to $6.7 \%$ in 2017 (pag. xii).Albeit in a difficult context, global FDls still represent "the largest source of finance for developing countries" (pag. xii).

\section{The positive influence of foreign direct investment over the host country}

In the economy literature, foreign direct investment and in particular, its positive or negative potential effects over the host economies, it is a widely debated issue.

It is well known that (Stoina, 2008) the companies from the well-developed countries which initiate direct investments in developing economies are beneficial for both parties involved. Thus, the former can achieve their objectives of production / assembly processes more efficiently while the host countries can better capitalize the human resources, natural or anthropogenic resources available.

Taking into account ( Popa, 2012, p.11) "a long-term relationship with a durable interest, as well as the regulator activity conducted by a resident entity in an economy, in another economy's resident company, foreign direct investment brings to the host country plentiful advantages and benefits". Some specialists (Caraganciu, et al., 2006) provide a comprehensive picture of the major benefic effects of the investment package for the recipient country's economy, pointing out the following: training qualified local human resource within the transnational companies, changing the behavior of internal companies by importing entrepreneurial culture, ensuring a productivity increase thanks to the modern technologies introduced by the transnational corporations, encouraging the emergence of new entrepreneurs in host countries by developing some cooperation contracts between transnational companies and local partners, introducing technological changes and increase of productivity at the level of local firms as a result of competitive pressures exerted by foreign branches.

Of course it is difficult to generate a hierarchy of advantages and benefits according to their importance, but we will point out some of them.

In terms of workforce quality, the transnational companies in general pay special attention to the degree of the employees' qualification and specialization which they recruit from the host country, knowing that the staff defines them, creates the value for them, promotes their image and also ensures the competitive advantage. Also, not by mistake, the specialists (Pandelică, 2007, p.74) have shown that one of the channels through which 
it is felt the transnational enterprises' contribution regarding the human resources' qualification and development within the countries in which they operate it is represented by "the continuous training actions and the training of the employees from their own companies and branches, provided with appropriate facilities". Also, some of the employees are given access to an international career and the opportunity of professional development living and working in a multicultural environment. Beyond this point of view, it must be emphasized the foreign companies' contribution in preparing the employees from other companies, based on the used methods, the recognition and rewarding of their own employees according to the skills and competences attained. In another train of thoughts, the relocated workers and managers to the local firms already own and bear relevant information about the new technologies or new management techniques becoming themselves direct agents of technology transfer (Serafim, 2015).

We also approve with the specialists' opinion (Ivan \& lacovoiu, 2008) who also from the positive and beneficial implications category consider that it is necessary to emphasize the incomes' increase to the state budget. It is also a natural consequence in the context in which, the economy of the host country, appear new taxpayers. Likewise, foreign direct investment also acts as a catalyst for internal investment, the aspect being motivated by the fact that the internal producers will manifest an increased interest in growing the efficiency and improving the quality of products and services offered in order to handle with the competitive pressure fueled by the presence of foreign investors in the sector in which it operates.

At the same time, "the positive impact on the commercial balance of these countries it is noticed, both by manufacturing locally some products which previously were imported and also by exporting some of these goods" (Diaconu Maxim, 2017, p.21).

In social terms, the literature (Stoian, 2010) argues the idea that foreign direct investment plays an important role for the level of employment, generating changes on the labor market, creating an additional need of workforce in those areas, but also it changes the investment's beneficiary's expectations, who directly operate new production capacities. This has as an immediate effect or more or less distant perspective, reducing the pressure of the factors which generate unemployment.

At all of these positive effects it is added another one which proves to be probably the most important effect of the foreign investment that local consumers can feel, namely, the enhancement of the living standards as a result of reducing the prices for goods and services. Thus, the foreign company's entry on a country's market will not only lead to product diversification and increased competition, but also to the prices' decrease for the most products and services.

\section{Can also be identified negative effects of the foreign direct investment on the recipient country?}

According to the specialists' opinion (Milea, 2015) beyond the positive effects, foreign investments can also generate a number of negative effects over the host country. In this category, for example, it must be mentioned, the local entrepreneurs removal from the local markets as a consequence of so called "predatory practices", such as "stealing" the clients and/or partners or acquiring local firms to annihilate them.From another 
perspective, it often happens that the local companies are not sufficiently prepared to compete with the multinationals.

The negative impact over the economic growth of the host country it is also manifested in the case of non-compliance of the business ethics' principles, such as the use of subterfuge to lower the level of income tax. Thus, one of the most common methods of tax optimization it is that of transfer pricing.

Negative effects may also emerge as a consequence of "the desire for efficiency through restructuring which favors the emergence of unemployment."On the other hand, the emergence of pollution can also have such an effect which can be manifested, especially "in the countries in which the environmental policy it is not restrictive"(Teodorescu, 2013, p.133).

\section{Conclusions}

The transnational companies which possess valuable assets, like: competitive management, technology, well known brands, access on big markets etc, represent the main manifestation of an authentic global economy. Without underestimating the role of the mergers and acquisitions, we consider that the completely new investments prove to generate more positive effects. In our opinion, it is in the host country's power to assimilate as completely and wholly as possible the advantages of foreign capital's presence, and to reduce the disadvantages through the policies it promotes.

\section{References}

Biró, D.(2013): Contemporary international relations. Central themes in world politics, Polirom Publishing House, lași.

Bîrsan, M., Mașca, S.G.(2012): Foreign direct investment: from the eclectic paradigm (OLI) to the paradigm of investment development (IDP), The Publishing House of the University Al.I.Cuza, lași.

Caraganciu, A., Cărare, A., Tverdun, L., Costandache, Gh. (2006): Changing economy: research and opinions, IEFS, Chișinău.

Ciobanu, M., (2015), Determinant factors of direct foreign investment. Engineering Meridian Journal no. 1, pp.69-74.

Cohn, T., H. (2016): Global political economy (seventh edition), Routledge, New York. Diaconu Maxim, L. (2017): Foreign investment, human capital and economic growth, The Publishing House of the University Al.I.Cuza, lași.

Horobeț, A., Popovici, O.(2017): Foreign direct investments: their evolution and importance in Romania, available online at https://www.researchgate.net/publication/321016706_INVESTITIILE_STRAI E_DIRECTE_EVOLUTIA_SI_IMPORTANTA_LOR_IN_ROMANIA/download

Ilie, G.(2009): International Investment (revised and added édition II), Pro Universitaria Publishing House, Bucharest.

Ivan, M., V., lacovoiu, V.,(2008), The role of foreign direct investments in the context of the obligation. Meeting the Convergence Criteria, Financial Studies Vol.12, no. $\quad 4$, pp.7392.

Milea, C.(2015), Foreign direct investments - a promoter or inhibitor of sustainable development?, The impact of socio-economic and technological transformations at national, 


\section{Studies in Business and Economics no. 14(1)/2019}

European and global level, No.7, available online at https://papers.ssrn.com/sol3/papers.cfm?abstract_id=2671288

Negrea, A., P., (2012), Globalization and Identity Dilemma, Theoretical and Applied Economics, Vol. XIX, No. 9, pp. 68-90.

Ogrean, C., Herciu, M., (2012), Theories of the multinational enterprises - two different approaches, Studies in Business and Economics, Vol.7, no.1, pp.138-142.

Pandelică, I.(2007): Transnational companies. Integrated Human resource management based of competence, Economic Publishing House, Bucharest.

Popa, S. (2012): Foreign direct investments in Romania: a quantitative approach, Pro Universitaria Publishing House, Bucharest.

Radu, L.( 2007), Competitiveness of multinational corporations, OEconomica, available online at http://oeconomica.org.ro/files/pdf/63.pdf

Stoian, M.(2010): The Management of Public investment, Academy of Economic Studies Publishing House, Bucharest.

Scholz, B. (2007): Investments: economic efficiency of investments, Risoprint Publishing House, Cluj - Napoca.

Stoina, C., N.(2008): Risk and investment uncertainty, Teora Publishing House, Bucharest.

Teodorescu, A.-M.(2013), The impact of foreign direct investment on sustainable development, available online

http://conferinta2013.academiacomerciala.ro/_VOLCONF2013PDF/volumc onferinta/Impactul\%20Investitiilor\%20Straine\%20Directe\%20asupra\%20de zvoltarii\%20durabile_TEODORESCU.pdf

Trufin,O.,S.(2015), Determinants of Foreign Direct Investment in the Receiving Country - Romania, available online

https://www.researchgate.net/publication/311514847_Determinants_of_Fo

reign_Drect_Investments_in_Host_Country_-_Romania

Tudose,G.(2012):Human resources management from the perspective of the convergence of competences with the labor market, AGIR Publishing House, Bucharest UNCTAD.(2018).World investment report, available online at https://unctad.org/en/pages/PublicationWebflyer.aspx?publicationid=2130

***http://www.oecd.org/daf/inv/investmentfordevelopment/2487495.p 